\title{
Aspects of Digitalization of Social Insurance in the Context of Analysis of the Effectiveness of the System of Mandatory Social Insurance of Industrial Injuries in the Russian Federation in the Period from 2005 to 2018
}

\begin{abstract}
Puinko L.E.
Far-East Institute of management, branch of the Russian Presidential Academy of National Economy and Public Administration (hereinafter RANEPA), Department of Economics and financial law, Khabarovsk 680000, Russia *Corresponding author.Email: lusiena_03@mail.ru
\end{abstract}

\begin{abstract}
Issues of digitalization of the social sphere and its component, such as mandatory social insurance in the development of the digital economy, are relevant today. At the same time, the Government of the Russian Federation is trying to "work ahead of the curve" in terms of transforming socio-economic processes, both within the country and in the world. The transition of insurance companies to IFRS, the approximation of domestic insurance standards to the world standards, the cleaning of the domestic insurance market from unreliable companies, the protection of ordinary workers with insurance tools and socio-economic mechanisms of their life and health in the workplace. - in all these processes, state institutions act as regulators and inspirers of creating the necessary digital platforms, information technology tools and software for medical, social and accounting solutions. In view of global changes in society and state institutions, the Government of the Russian Federation builds its activities, including in the insurance sector, from the position of fulfilling social obligations to citizens. In addition, business is never interested in social protection of its employees; for commercial insurance companies, such types of insurance as industrial injuries and occupational diseases insurance are obviously not profitable; and such insurance can only be carried out under pressure from the state authorities: i.e. this relationship of domination and subordination, based on organizing influence and the possibility of coercion by the state to perform, among other things, the function of social protection of the population.
\end{abstract}

Keywords: digital economy, industrial injuries, social insurance, social insurance against accidents,

information resources, digital services

\section{HISTORICAL ASPECT OF THE DEVELOPMENT OF THE SYSTEM OF COMPULSORY SOCIAL INSURANCE OF INDUSTRIAL INJURIES IN THE RUSSIAN FEDERATION}

\footnotetext{
After the collapse of the USSR in 1992, Russia began their work two major insurance companies - Rosgosstrakh, converted in February 1992, as successor to Gosstrakh of RSFSR [1], [3], and Ingosstrakh, which was the successor of the Main Department of foreign insurance of the USSR [1], [4]. At the same time, in 1992, the law "on the organization of insurance business in the Russian Federation" was adopted and a body for supervision of the
}

activities of insurers was established - Rosstrakhnadzor of the Russian Federation [2], [6].

Further, from 1992 to 1996 , there was a rapid growth of insurance companies, only due to the fact that many business owners used schemes to evade taxes by paying their employees wages, in the form of insurance payments under a life insurance contract concluded by the employer in favor of an employee, under the terms of which the insured event is the employee's survival until the payday [1], [5], [6].Thus, the true meaning of both the salary itself and the essence of personal insurance was replaced, which in principle did not take into account the rules of inheritance law, including receiving insurance (compensation) payments in case of loss of the breadwinner by his heirs (usually relatives). 


\subsection{The need for the law "On compulsory social insurance against industrial accidents and occupational diseases"}

As the number of insurance organizations grew, so did the number of insurance agents, the amount of contributions, the number of actuaries, and insurance experts [1], [5], [6]. In the system of secondary and higher education, there was also a sharp decline in educational programs and directions for training specialists in the insurance sector. With the growth of the number of insurance companies, the lack of demand for specialists in the insurance industry, and the curtailment of insurance training programs, it looked at least strange, if you do not take into account the real processes taking place in this area. I. e. in the period from 1992 to 1996, pseudo-insurance developed [2]. Moreover, life insurance and especially life insurance for the population, the majority of insurance companies was not provided, as sharp jumps in inflation, the sharp drop in the standard of living of the population, lack of savings and available funds not contributed to the development of life insurance and General personal insurance. In the period since 1992. until 1998, in the Russian Federation, the obligation of the employer to take care of the life and health of its employees (employees) was very vague, in fact, it was voluntary. In 1998, the Federal law "on mandatory social insurance against industrial accidents and occupational diseases" - № 125 FZ of 24.07.1998 [7], according to the text of the law, mandatory social insurance against occupational diseases and industrial accidents is subject to: individuals working on the basis of an employment agreement concluded with the insured (i.e., with the employer); individuals sentenced to imprisonment who are employed by the insured (employer). Individuals who perform work based on civil contracts are subject to mandatory social insurance against occupational diseases and industrial accidents, if under the specified contract, the policyholders (employers) are required to pay insurance premiums to the insurer.

In addition to social insurance, there is also mandatory health insurance for employees ' life and health. Since 1998, the state has been developing a scheme for regulating the obligations of employers to protect the life and health of their employees, as well as the implementation of mandatory social insurance standards.

Since 1998, with the introduction of the law on "compulsory social insurance against industrial accidents and occupational diseases", the personal insurance industry has returned to its true meaning, which is expressed in the systems of medical insurance (primarily mandatory, but also voluntary), pension insurance (both mandatory and voluntary), and social insurance against accidents (primarily mandatory).

The Federal Insurance Supervision Service regulated legal relations in the insurance sector from March 2004 to March 2011, and before that, the insurance supervision Department of the Russian Ministry of Finance was the insurance regulator. On 04.03.2011, by presidential decree, the Federal insurance Supervision Service (FSSS) was abolished and its functions transferred to the Federal Financial Markets Service (FSFR). then, on 01.09.2013, by presidential decree, the Federal Financial Markets Service was abolished and its functions transferred to the Central Bank of Russia [1], [5], [6], [8]. In parallel with changes in the processes of compulsory insurance, changes in regulators, there are significant changes in medical and pension insurance. In particular, the changes associated with digitization.

\subsection{Analysis of indicators of the mandatory social insurance system for industrial injuries in the Russian Federation}

Referring to the data of the Federal state statistics service in the field of insurance activities, with regard to personal insurance and mandatory life insurance, Rosstat does not share the information that relates, for example, to mandatory life insurance for mortgage lending and mandatory life insurance for employees of hazardous industries, however, according to Rosstat data.

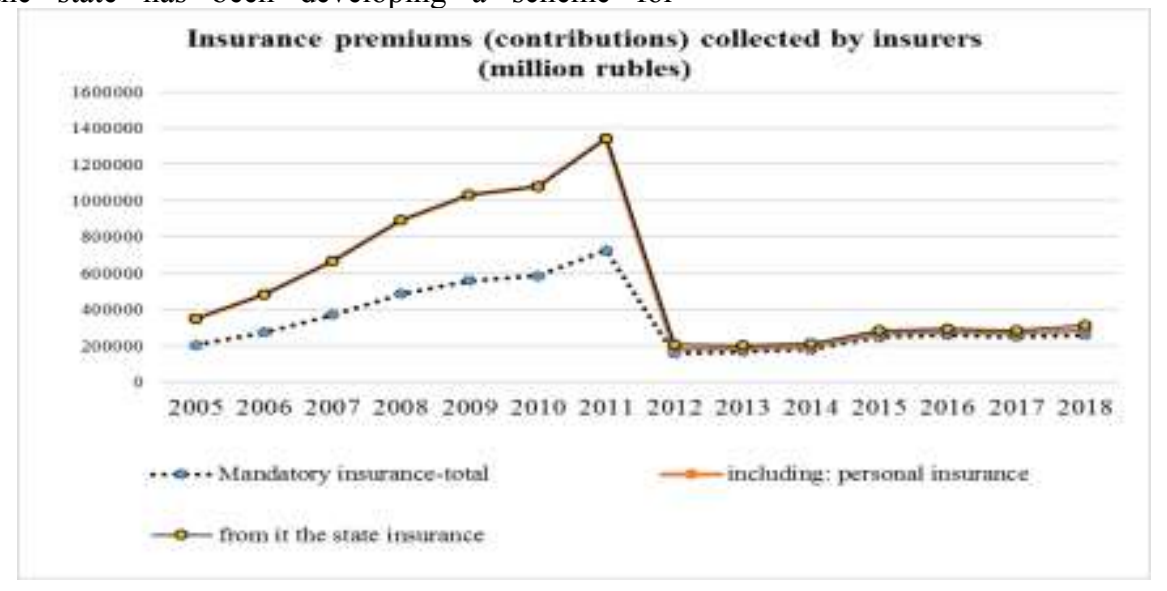

Figure 1 Insurance premiums collected by insurers [10] 
Table 1 Insurance premiums collected by insurers (million rubles) [10]

\begin{tabular}{|c|c|c|c|c|c|c|c|c|c|c|c|c|c|c|}
\hline & 2005 & 2006 & 2007 & 2008 & 2009 & 2010 & 2011 & 2012 & 2013 & 2014 & 2015 & 2016 & 2017 & 2018 \\
\hline $\begin{array}{c}\text { Mandatory } \\
\text { insurance-total }\end{array}$ & $\begin{array}{l}0 \\
\stackrel{0}{*} \\
\stackrel{\text { ते }}{0}\end{array}$ & 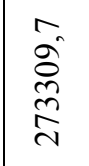 & 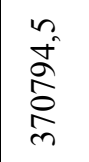 & $\begin{array}{l}\infty \\
2 \\
\infty \\
\stackrel{人}{ } \\
\infty \\
\infty\end{array}$ & 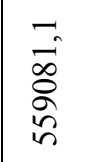 & \begin{tabular}{l}
0 \\
i \\
\multirow{0}{0}{} \\
$\infty$ \\
$\infty$ \\
$\infty$
\end{tabular} & 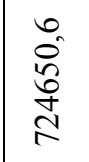 & $\begin{array}{l}1 \\
0 \\
0 \\
0 \\
0 \\
0 \\
n \\
n\end{array}$ & $\begin{array}{l}m \\
n \\
0 \\
0 \\
0 \\
0 \\
0\end{array}$ & 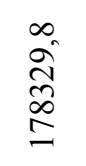 & $\begin{array}{l}\overrightarrow{0} \\
\stackrel{\infty}{\stackrel{\infty}{*}} \\
\stackrel{+}{\sim}\end{array}$ & 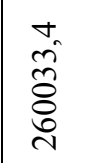 & 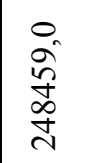 & 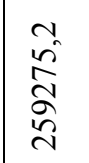 \\
\hline $\begin{array}{c}\text { including: } \\
\text { personal insurance }\end{array}$ & 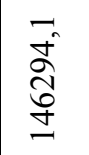 & $\begin{array}{l}\text { Oे } \\
\text { ळे } \\
\text { ᄋे }\end{array}$ & 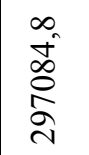 & $\begin{array}{l}2 \\
\hat{o} \\
\dot{\delta} \\
\stackrel{0}{o}\end{array}$ & 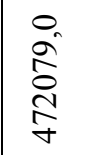 & 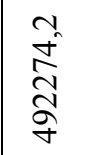 & $\begin{array}{l}n \\
\infty \\
\infty \\
\frac{\infty}{\sigma}\end{array}$ & $\begin{array}{l}\infty \\
\hat{n} \\
\hat{n}\end{array}$ & $\begin{array}{l}0 \\
\infty \\
\infty \\
\infty \\
\infty\end{array}$ & 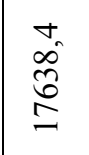 & $\begin{array}{l}n \\
\tilde{\sigma} \\
\infty \\
\infty\end{array}$ & $\begin{array}{l}\hat{\text { ⿵े }} \\
\text { Iิ }\end{array}$ & $\begin{array}{l}m \\
\infty \\
\infty \\
\infty \\
\infty\end{array}$ & $\frac{n}{i}$ \\
\hline $\begin{array}{c}\text { from it the state } \\
\text { insurance }\end{array}$ & $\vdots$ & $\vdots$ & $\vdots$ & $\vdots$ & $\vdots$ & $\vdots$ & $\vdots$ & $\begin{array}{l}\overrightarrow{8} \\
\stackrel{2}{+}\end{array}$ & \begin{tabular}{l}
3 \\
\multirow{f}{f}{} \\
$\infty$ \\
$=$
\end{tabular} & $\begin{array}{l}\stackrel{\sigma}{n} \\
\stackrel{n}{n} \\
\end{array}$ & 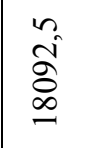 & $\vec{n}$ & $\begin{array}{l}n \\
\infty \\
心 \\
\infty \\
\infty\end{array}$ & $\frac{m}{i}$ \\
\hline
\end{tabular}

You can see the dynamics of collected premiums (figure 1, table 1), health insurance premiums up to 2012 (table 3), before the introduction of the Federal law "On mandatory medical insurance in the Russian Federation" from 29.11.2010 N 326-FZ [9], as well as the insurance amounts paid (compensation) in terms of mandatory life insurance in Russia as a whole (table 2, figure 3) [10], [11].

According to statistics, it can be seen that the volumes of state and personal insurance coincide in almost the entire period under review from 2005 to 2018 . At the same time, the state in the period from 2005 to 2011 assumed almost twice as many obligations as "compulsory insurance". The same information is provided in table 1 below. Similarly, the volume of payments for state and personal insurance obligations coincides almost throughout the period under review from 2005 to 2018 . The schedule of the "mandatory insurance" category reflects a smaller number of payments before 2011 than for state insurance, but in the last years of 2012-2018, the volume of payments for state and mandatory insurance almost coincided (figure 2, table 2).

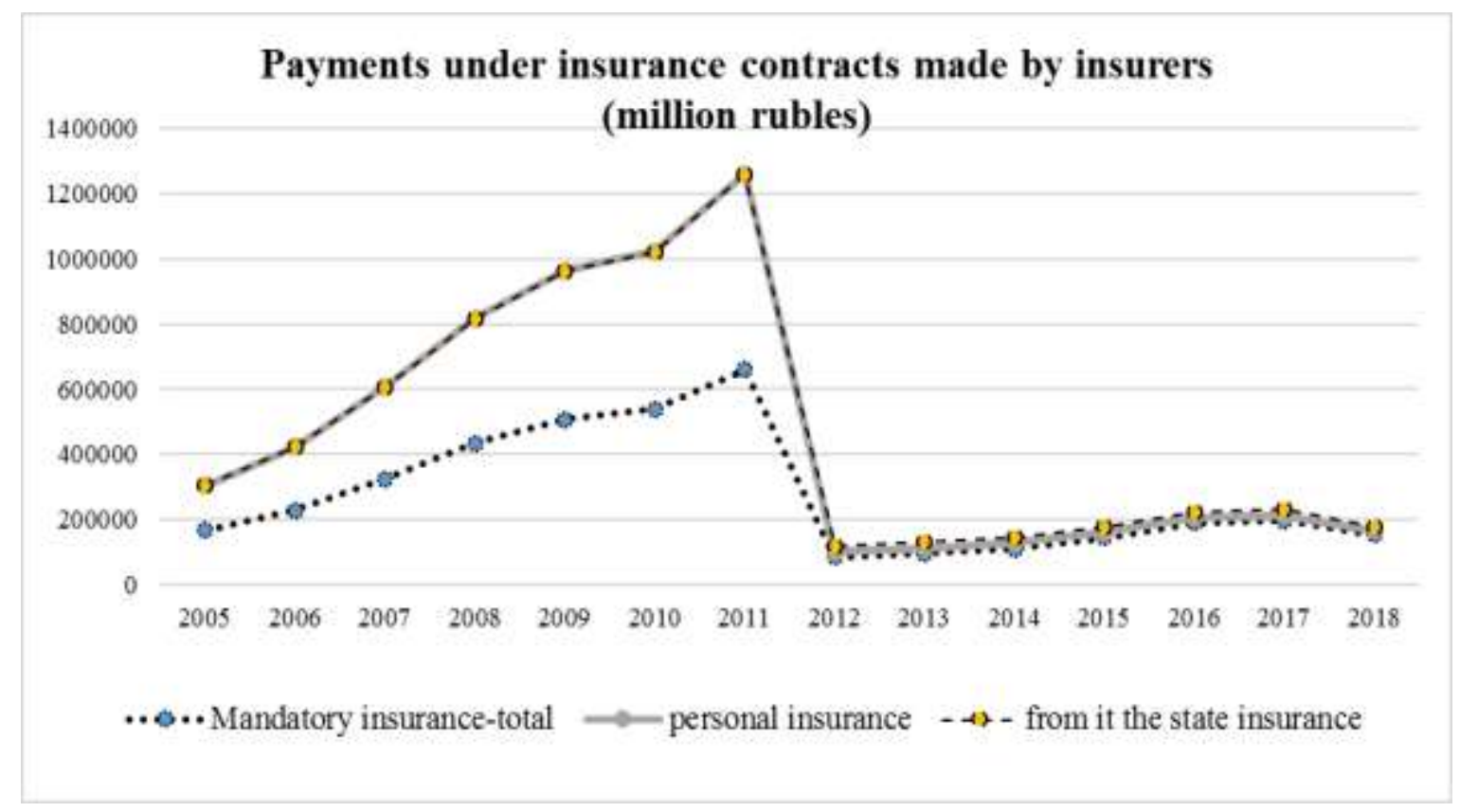

Figure 2 Payments under insurance contracts made by insurers [10] 
Table 2 Payments under insurance contracts made by insurers (million rubles) [10]

\begin{tabular}{|c|c|c|c|c|c|c|c|c|c|c|c|c|c|c|}
\hline & 2005 & 2006 & 2007 & 2008 & 2009 & 2010 & 2011 & 2012 & 2013 & 2014 & 2015 & 2016 & 2017 & 2018 \\
\hline $\begin{array}{c}\text { Mandatory } \\
\text { insurance-total }\end{array}$ & $\begin{array}{l}n \\
\tilde{\delta} \\
\delta \\
0 \\
0 \\
0\end{array}$ & $\begin{array}{l}\overrightarrow{-} \\
\vec{J} \\
\stackrel{\infty}{\Delta}\end{array}$ & 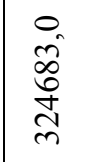 & 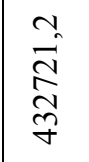 & $\begin{array}{l}0 \\
\text { to } \\
\hat{2} \\
\hat{0} \\
i n\end{array}$ & 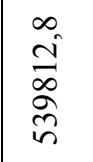 & 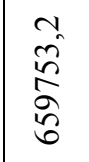 & 总 & $\begin{array}{l}\infty \\
\vdots \\
\vdots \\
n \\
n\end{array}$ & $\begin{array}{l}\infty \\
\stackrel{\infty}{8} \\
8 \\
=\end{array}$ & $\begin{array}{l}\text { I } \\
\text { G্ } \\
\stackrel{\sim}{J}\end{array}$ & $\begin{array}{l}\underset{\hat{\sigma}}{+} \\
\hat{\infty} \\
\infty \\
\infty\end{array}$ & 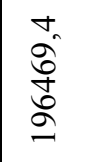 & 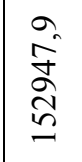 \\
\hline $\begin{array}{l}\text { including: } \\
\text { personal insurance }\end{array}$ & 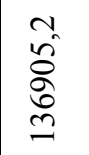 & 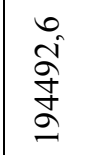 & 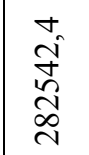 & $\begin{array}{l}\vec{a} \\
\tilde{\delta} \\
\stackrel{\pi}{+} \\
\infty \\
\text { nd }\end{array}$ & 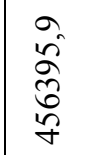 & 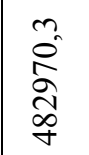 & 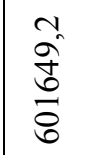 & 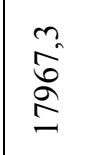 & $\begin{array}{l}+ \\
\stackrel{+}{n} \\
i \\
-\end{array}$ & 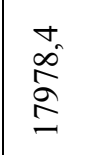 & $\begin{array}{l}\vec{\infty} \\
\stackrel{n}{I}\end{array}$ & $\begin{array}{l}\overrightarrow{6} \\
\infty \\
n\end{array}$ & $\begin{array}{l}\overrightarrow{0} \\
\text { है }\end{array}$ & $\vec{a}$ \\
\hline $\begin{array}{l}\text { from it the state } \\
\text { insurance }\end{array}$ & $\vdots$ & $\vdots$ & $\vdots$ & $\vdots$ & $\vdots$ & $\vdots$ & $\vdots$ & $\begin{array}{l}0 \\
\hat{n} \\
2 \\
\end{array}$ & 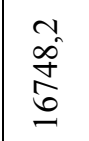 & $\begin{array}{l}\hat{\infty} \\
\stackrel{0}{0} \\
\stackrel{1}{1}\end{array}$ & 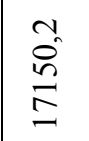 & $\begin{array}{l}\overrightarrow{6} \\
\infty \\
n\end{array}$ & $\begin{array}{l}\overrightarrow{0} \\
\text { है }\end{array}$ & 六 \\
\hline
\end{tabular}

As for the costs of mandatory medical insurance, over the 29.11.2010 N 326-FZ), they have increased three times, past almost ten years (since the law was introduced on and this is primarily the fees of employers.

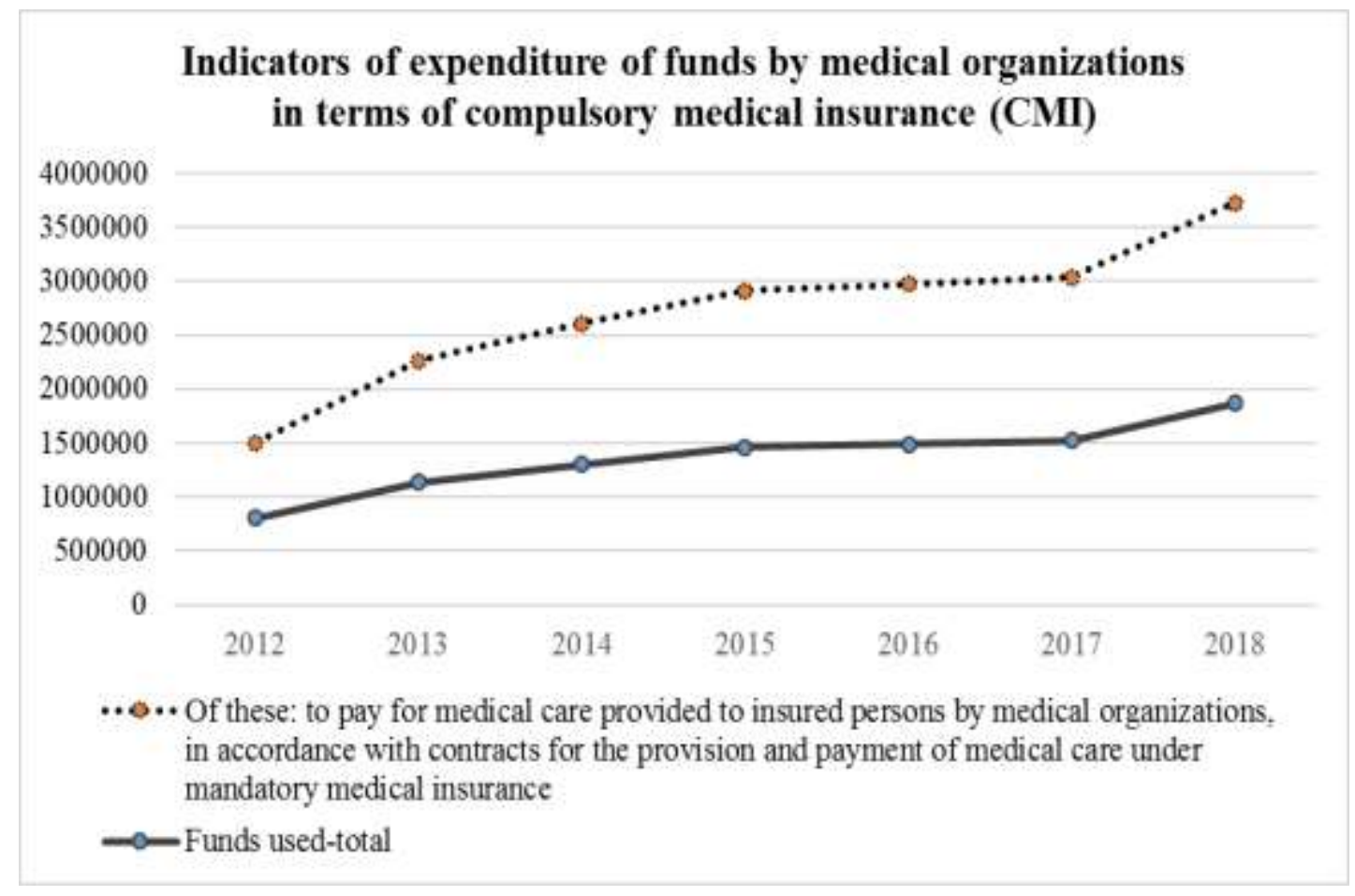

Figure 3 Indicators of expenditure of funds by medical organizations in terms of mandatory medical insurance (MHI) (million rubles) [10]

At the same time, during the entire period of industrial accident insurance, state bodies monitored the implementation of legislation in the field of labor protection, which led to a significant reduction in industrial deaths, data based on Rosstat data are presented below in figure 3 [11]. 


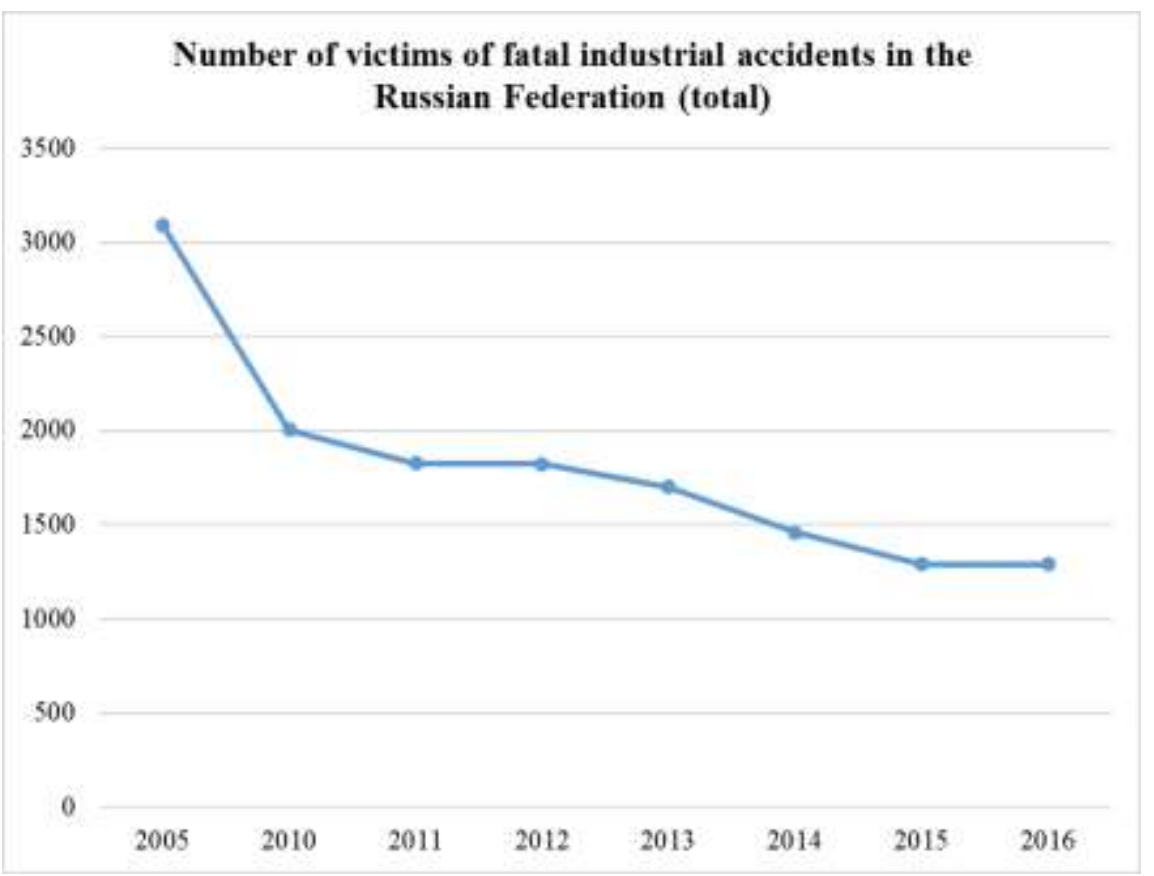

Figure 4 Number of victims of fatal industrial accidents [11]

The number of deaths at work was reduced three times due to consolidated measures, including the introduction of safety and control systems.

\subsection{Projects of digital services for mandatory social insurance of industrial injuries in the digital economy in Russia}

Among the main projects of social services in the digital economy and digital management today are the electronic disability list and payments to the MIR card. Projects related to electronic reporting of policyholders, control over the activities of insurance companies through the digital environment, and their solvency are being developed. Developers of medical and accounting software solutions are interested in implementing electronic sick lists, switching to digital reporting, etc. In 2018, the FSS introduced a blockchain technology-a network for storing archived records on electronic hospital records [12].

Projects to digitalize employers ' reporting, including in the field of mandatory social insurance, to increase the transparency of the fulfillment of social obligations of employers to their employees. Especially, the implementation of social insurance standards for employees is important for dangerous industries, because the owners of dangerous production facilities hide small accidents (statistics show that in Russia, one person is injured per person killed in dangerous production, while the average European indicators are less terrible, due to the strict discipline of mandatory insurance and increased control by trade unions). Thus, the social insurance Fund is moving to a digital platform, the main purpose of which is to simplify the provision of public services in the field of social insurance, their convenience and transparency.

The Russian insurance market is developing, and over the past five years has suffered a lot of shocks: sanctions, which were imposed on Russian insurers, the change of the regulator, the transition to the international financial reporting system (IFRS), in the light of the fact that the market has a lack of qualified specialists who can prepare reports in accordance with IFRS (the formation of an insurance company's accounting policy in accordance with the requirements of IFRS is now mandatory); introduction of a list of regulations by the Central Bank of Russia [13] concerning control in the sphere of insurance activity; problems of the reinsurance market (lack of reinsurance capacities) and some other challenges that require insurers to urgently address them[14], [15], [16], [17].

\section{OPTIMIZATION MEASURES TO REDUCE INJURIES OF WORKERS IN HAZARDOUS INDUSTRIES IN THE DIGITAL ECONOMY}

\subsection{Improving the Russian insurance market}

The Russian insurance market should be improved in several ways. It is necessary to improve the Executive discipline of owners of dangerous industries in terms of mandatory insurance of their liability to their employees. 
number of measures in the digital economy to minimize industrial injuries, reduce accidents at work, and help victims in rehabilitation, taking into account existing insurance practices and control in this area. Insurance payments, such as financial assistance for rehabilitation after an accident, are certainly necessary, but it is even more important that victims and their families are not left alone with their troubles. The death of people in the workplace can not be compensated by any payments; and recovery of health after injuries and the development of occupational diseases is not always possible, and requires a lot of money. Therefore, it is necessary to prevent such cases, and modern digital technologies, artificial intelligence systems and blockchain systems are used for this purpose.

\section{ACKNOWLEDGMENT}

\subsection{Projects for the digital platform «Digital transformation of social insurance»}

At the same time, the development of the digital platform "Digital transformation of social insurance" includes:

"Smart social insurance", drawing up individual programs based on special formulas that personally calculate contributions based on the " Passport of the insured»;

"Individual programs and measures for the prevention of occupational diseases" that monitor the health of employees in order to prevent and treat occupational diseases in a timely manner;

"Prevention of accidents at work" - complexes for monitoring the working conditions and condition of the insured in hazardous production conditions;

"Comprehensive individual rehabilitation" - returning the victim to the highest possible quality of life and work.

That is, the mechanisms of the digital platform "Digital transformation social insurance" includes not only the investment of financial assets in part of payments by results of accidents in the workplace, and what is very important system monitoring and control to prevent accidents and industrial injuries, as such; and if a person gets harmed, the social security program rehabilitates it to the highest possible quality of life and work. [12]

Such systems are currently being developed primarily on the basis of blockchain technologies, artificial intelligence and neural network technologies.

The development of the digital platform also involves the creation of a social "business Communicator" - a connector between policyholders and companies of medium and small businesses. This will be an integrated digital mobile platform for information interaction between the Fund and small and medium-sized businesses [12]. Social Navigator services are being developed on the basis of the digital platform [12].

Thus, the Government of the Russian Federation, the social insurance Fund, the Treasury, the Ministry of labor and social protection of the Russian Federation, and the Pension Fund of Russia have developed a
This work was supported by Far-East Institute of management, branch of the Russian Presidential Academy of National Economy and Public Administration (hereinafter RANEPA), Department of mathematical methods and information technologies, Khabarovsk 680000, Russia.

\section{REFERENCES}

[1] History of insurance development in Russia. Website of the representative office of the all-Russian Union of insurers in the Siberian Federal district. // [Electronic resource]. - Mode of access: http://sibinsur.ru/ofni02-1.htm

[2] History of insurance and reinsurance. Website about resource]. - Mode of access: http://www.askins.ru/index.php/story-i

[3] About company. Rosgosstrakh. // [Electronic resource]. - Mode of access: http://www.rgs.ru/about/information/index.wbp

[4] Ingosstrakh. Company history. // [Electronic resource]. - Mode of access: http://www.ingos.ru/ru/company/company-history/

[5] Historical and legal problems of insurance Institute development in Russia (Soviet period). Siberian Association of consultants. Correspondence scientific and practical conferences. Report of Ivan V. Makerov, expert specialist of the legal Department of the Department of the Pension Fund of the Russian Federation for the Belgorod region, Belgorod. // insurance and risk management. // [Electronic 
[17] Bykanova N. I., Cherkashina A. S. Insurance market of Russia: problems and directions of development / / Young scientist. - 2017. - \#10. - Pp. 204-207. // [Electronic resource]. - Access mode: https://moluch.ru/archive/144/40382/ (accessed: 29.03.2020).
[6] Russian insurance market: some characteristics of extensive and intensive development. candidate of economic Sciences Yu. V. Neradovskaya. // [Electronic resource]. - $\quad$ Mode of access: http://finbiz.spb.ru/download/2_2011/neradov.pdf

[7] Federal law of July 24, 1998 N 125-FZ "on mandatory social insurance against industrial accidents and occupational diseases" Electronic resource of the SPS "Garant" / / [Electronic resource]. — Mode of access: https://base.garant.ru/12112505/

[8] Statistical indicators and information about individual subjects of the insurance market. CBR. // [Electronic resource]. — Mode of access: http://cbr.ru/finmarkets/?PrtId=sv_insurance

[9] Federal law "on mandatory medical insurance in the Russian Federation" of 29.11.2010 N 326-FZ / electronic resource of the SPS "Consultant Plus" / /[Electronic resource]. — Mode of access: http://www.consultant.ru/document/cons_doc_LAW_1 07289/

[10] Official data of the Federal state statistics service / /[Electronic resource]. — Mode of access: https://www.gks.ru/folder/11192

[11] Official data of the Federal state statistics service / /[Electronic resource]. — Mode of access: https://www.gks.ru/working_conditions

[12] Information technologies in the social insurance Fund of the Russian Federation( FSS): Projects for the development of the social insurance Fund. - Mode of access: http://zdrav.expert/index.php / Article: Information_technology_in_conde_social_insurance_rf (FSS)

[13] Central Bank of the Russian Federation / /[Electronic resource]. — Mode of access: http://www.cbr.ru/

[14] Reference portal about insurance / /[Electronic resource]. — Mode of access: http://risk-insurance.ru

[15] Insurance news Agency / /[Electronic resource]. Mode of access: http://www.asn-news.ru

[16] Insurance today [Electronic resource]. — Mode of access: http://www.insur-info.ru/statistics/analytics. 